\title{
Ignacio Arellano, El ingenio de Lope de Vega. Escolios a las «Rimas humanas y divinas del licenciado Tomé de Burguillos», Nueva York, IDEA/IGAS, 2012, 310 pp. (ISBN: 978-7-938795-84-8).
}

\section{Fernando Rodríguez Mansilla}

Hobart and William Smith Colleges

208 Smith Hall

Department of Spanish and Hispanic Studies

300 Pulteney St.

Geneva, NY 14456, EE. UU.

Estados Unidos

mansilla@hws.edu

[Hipogrifo, (issn: 2328-1308), 1.2, 2013, pp. 205-207]

Recibido: 30-05-2013 / Aceptado: 27-06-2013

DOI: http://dx.doi.org/10.13035/H.2013.01.02.18

En el panorama crítico actual en torno a la literatura áurea, este libro resulta muy original y pertinente. El ingenio de Lope de Vega es una invitación no solo a releer las Rimas humanas y divinas del heterónimo Tomé de Burguillos, sino a volver a los textos primarios y ahondar en el sentido literal, del que nos inculcó Marcel BatailIon nunca olvidarnos ( $\mathrm{y}$ a veces lo hemos hecho, lamentablemente). El interés de Ignacio Arellano en este conjunto poético surge de su evaluación acerca del estado editorial de esta obra lopesca, que no es precisamente precario en cantidad. Arellano fija su atención en las ediciones más recientes y solventes hasta el momento: la de Antonio Carreño (2002), la de Juan Manuel Rozas y José Cañas Murillo (2005), y la de Macarena Cuiñas Gómez (2008). Los escolios o notas filológicas sueltas que explican e ilustran los versos de Burguillos dialogan críticamente con estas tres ediciones, cuyas notas Arellano comenta y amplía, en pro de exprimir el lenguaje ingenioso que empapa la obra.

De manera que el propósito que guía El ingenio de Lope de Vega aparece como humilde, en contraste con vuelos interpretativos más ambiciosos que se han prodigado al Fénix, pero no por ello resulta menos certero o profundo. En verdad, resulta llamativo el hecho -como lo recalca Arellano- de que se hayan postulado lecturas más o menos orgánicas de este volumen poético de tono jocoso sin haber esclarecido del todo ciertos versos o, lo que es peor inclusive, habiendo malinterpretado algunos por falta de pericia filológica o desinterés editorial. Quizás bajo la 
excusa de la llaneza que Góngora y otros autores de la época atribuían al estilo de Lope (que él mismo suscribía y defendía), los críticos de ahora han pasado por alto indagar a fondo en el significado concreto de tal o cual verso. Sin embargo, como el investigador resalta, aquel lenguaje aparentemente llano no supone ausencia de ingenio, el cual da sentido al ejercicio literario como delectare en el Siglo de Oro. A veces la crítica descuida estos artificios propios de la lengua áurea, pero ocurre que, precisamente, su dilucidación revela un significado con hondas reverberaciones ideológicas y culturales. Lo que media entre comprender un chiste o no verlo, nos da la pauta de lectura que separa la ironía o la frivolidad de una toma de posición firme o una heterodoxia. La discusión no es ociosa, ya que nos devuelve al debate en torno a la risa en el Siglo de Oro, a cuáles son los límites entre las burlas y las veras, así como a la tensión entre locutor poético y autor.

Bajo esta preceptiva, Arellano elabora una propuesta de anotación filológica que aboga, ante todo, por la precisión: más importante que comentar las muchas connotaciones de un término, que redunda en vana erudición, es encontrar la acepción exacta con la que lo usa el poeta; tan o más relevante que determinar el sentido recto del término empleado es explicarlo en el contexto que ofrece el poema. Arellano establece que la anotación debe guardar tres tipos de coherencia, que se retroalimentan entre sí: coherencia gramatical, semántica y poética. Siguiendo este criterio, amparado por la erudición medida y el método de pasajes paralelos, el filólogo explica y comenta versos hasta ahora mal entendidos o simplemente ininteligibles dentro de la tradición editorial de las Rimas humanas. Con una sencillez expositiva que no impide echar mano de las figuras de agudeza teorizadas por Baltasar Gracián, los escolios que componen El ingenio de Lope de Vega nos pueden mostrar los límites de la interpretación literaria, a partir del debate con los editores previos. A veces llevados ciegamente por prejuicios críticos (como asumir que los poemas de las Rimas humanas encierran exclusivamente un ataque a Góngora y su estilo) o por lecturas sin contexto (interpretar un verso aislado, sin leerlo en función del poema como un todo), los editores no solo desorientan al lector, sino que fijan las lecturas erróneas o simplemente vagas del texto editado.

La labor que forja El ingenio de Lope de Vega es ardua: si bien el investigador descifra muchas dificultades lopescas (teniendo para ello que proponer nuevas puntuaciones o enmendar versos), también deja testimonio de versos aún impenetrables. Sin embargo, a través de su método didáctico y claro, Arellano sale airoso de la empresa y logra contribuir de forma sustancial al mejor conocimiento de esta parcela lírica eminentemente burlesca a la que Lope puso tanto esmero. De paso, ofrece al lector un útil repertorio de notas y comentarios filológicos que pueden ayudarlo a comprender otros textos de la época. La lectura es amena y ágil, adornada con emblemas e imágenes que apoyan la argumentación, rica en bibliografía y una tabla final para localizar los poemas comentados.

En conclusión, El ingenio de Lope de Vega es una lectura sumamente recomendable para comprender el lenguaje conceptista y sus recursos, a luz de los poemas burlescos más logrados de Lope. Ignacio Arellano alcanza a demostrar su hipótesis inicial: la llaneza de Lope no implica ausencia de artificio o elaboración 
conceptista. La dificultad expresiva configura el punto de partida y llegada de su arte literario, como el de todo poeta que se preciara en el Siglo de Oro. He aquí los prolegómenos a la lectura global de las Rimas humanas y divinas de Tomé de Burguillos, aún por hacer. 
